\title{
HISTOTOPOGRAPHY OF SELECTED ENZYMES IN THE LIVER OF CALVES ON STANDARD AND Ca-DEFICIENT DIETS
}

\author{
F. TICHÝ and D. HORKÝ
} Department of Anatomy, Histology and Embryology, University of Veterinary Science,
61242 Brno

Received December 2, 1982

\begin{abstract}
Tichý F., D. Horký; Histotopography of Selected Enzymes in the Liver of Calves on Standard and Ca-deficient Diets. Acta vet. Brno, 52, 1983: $131-143$.

Histochemical demonstration of enzymes in the liver of calves reared on a standard and a Ca-deficient diet is presented with regard to possible changes in the intensity of catalytic enzyme activity due to calcium deficiency.

Liver tissue samples were collected from two calves fed a $\mathrm{Ca}$-deficient diet and one animal fed a standard diet. The calves were 2 months old. By means of specific reactions the following enzymes were demonstrated: alkaline phosphatase (EC 3.1.3.1); acid phosphatase (EC 3.1.3.2), lactic dehydrogenase (EC 1.1.1.27), succinic dehydrogenase (EC 1.3.99.1), glycerophosphate dehydrogenase (EC 1.1.1.8), and non-specific esterase (EC 3.1.1.1) Further, polysaccharides were determined by the PAS method.

Besides the histotopographic determination of the above mentioned enzymes, semiquantitative comparison of intensity of their catalytic activities was made.

Evaluation of these data indicated differences in liver enzyme endowment between the experimental and control animals, particularly as far as the catalytic activity of both phosphatases, lactate dehydrogenase and non-specific esterase are concerned. These enzymes seem to be affected by the calcium deficiency in the diet. There were no substantial differences in topography of the enzymes.
\end{abstract}

Catalytic activity, enzymes, topography, Ca-deficiency, diet.

Intensive research into the liver functions from the viewpoint veterinary diagnosis has been carried out since about 30 years. Major contributions to our knowledge are those of clinical biochemistry and pathological physiology.

Histochemical evidence of enzymes has usually been mentioned with regard to experimental methods (Lojda 1966; Vacek 1972) or to biochemical quantitative determination of enzyme activities (Pojer et al. 1963). The majority of literature data have been oriented to clinical hepatology and differential diagnosis of liver diseases (Hegglin 1972; Pojer et al. 1968; Ganong 1978).

In this work histochemical evidence of several enzymes in the liver is presented. Special attention was given to enzyme topography in the liver parenchyma. The data were obtained from calves fed different diets and the effect of the diets was considered, too.

\section{Materials and Methods}

Liver samples were collected from 2 calves fed a Ca-deficient diet from the age of 1 week until the day of sampling at the age of 2 months, and from one control calf of the same age fed a standard diet (see Table 1). The bioptic samples were immediately frozen and cut with a CRYO-CUT (American National Corporation). 
Table 1

Experimental animals and their diets

\begin{tabular}{|c|c|c|c|c|}
\hline $\begin{array}{c}\text { Calf } \\
\text { No. }\end{array}$ & $\begin{array}{c}\text { Body mass } \\
\text { kg }\end{array}$ & Sex & Age & Diet \\
\hline 1 & 68.0 & 0 & 2 months & standard \\
2 & 70.0 & 0 & Ca-deficient \\
3 & 72.5 & $\hat{o}$ & Ca-deficient \\
\hline
\end{tabular}

Explanations: The calf No. 1 was fed milk replacer Laktosan (10 1/day) and corn granules ad libitum

Calves No. 2 and 3 were fed the same diet + complexon EDTA 3 (Natrium salt EDTA) at a dose of $30 \mathrm{mg} / \mathrm{kg} / \mathrm{day}$

The sections were immediately attached to glass and fixed

a) in Baker's fluid prior to reaction for alkaline and acid phosphatases,

b) postfixed in $10 \%$ formaldehyde after the reaction for dehydrogenases.

Principles of the histochemical enzyme demonstration (Lojda 1966):

1) Alkaline phosphatase (EC 3.1.3.1): this monoesterase was demonstrated by the diazotizating and coupling reaction in an incubation medium with $\alpha$-naphthylphosphate. Naphthol cleaved by the enzyme reacts with the diazonium salt to form the azo-dye. This specific reaction yields a brown-coloured product located on cell membranes.

2) Acid phosphatase (EC 3.1.3.2): for demonstration of its activity the diazotization and coupling reaction with phosphorous esters of naphthol AS was used. The reaction principle is the same as with alkaline phosphatase. The reaction product located at sites of enzyme activity is light red.

3) Lactic, succinic and glycerophosphate dehydrogenases (EC 1.1.1.27, EC 1.3.99.1 and EC 1.1.1.8): the reaction principle is the same for all three enzymes. Tetrazolium salts employed for demonstration of the catalytic enzyme activity are poorly soluble and coloured in their oxidized form; when reduced by hydrogen, they yield blue and insoluble formazane. Blue areas of the reaction are indicative of the enzyme activity.

4) Non-specific esterase (EC 3.1.1.1): diazotizating and coupling reaction was used for demonstration of this enzyme. Its principle lies in cleavage of the substrate ( $\alpha$-naphthylacetate) by the enzyme action. The free naphthol yields azo-dye with diazonium salt. The reaction product is black.

5) Polysaccharides: were demonstrated using the PAS method. By action of periodic acid aldehydes are formed and they react with Schiff's reagent yielding a red-violet substance with intracellular location.

\section{Results}

For demonstration of the catalytic enzyme activities methods yielding colour products were employed. The product is located predominantly at sites of highest enzyme activity thus indicating enzyme topography. The amount and colour intensity of the reaction product is directly related to the activity of the enzyme. These histochemical findings are therefore suggestive of the activity of the respective enzyme in a tissue or organ.

In our experiment the method of semiquantitative comparison of colour intensity was used for baseline data on enzyme activities. The findings in 2 experimental calves were compared with those in one control animal in liver samples of which the colour intensity was graded 3. Different colour intensity found in experimental calf liver samples was expressed by adequate change in the colour index (graded 0 to 6$)$.

1) Alkaline phosphatase (Fig. 1 and 2) was predominantly located on cell membranes of biliary poles of hepatocytes. The enzyme activity determined semiquantitatively appeared to be substantially higher in experimental calves (grade 5). 

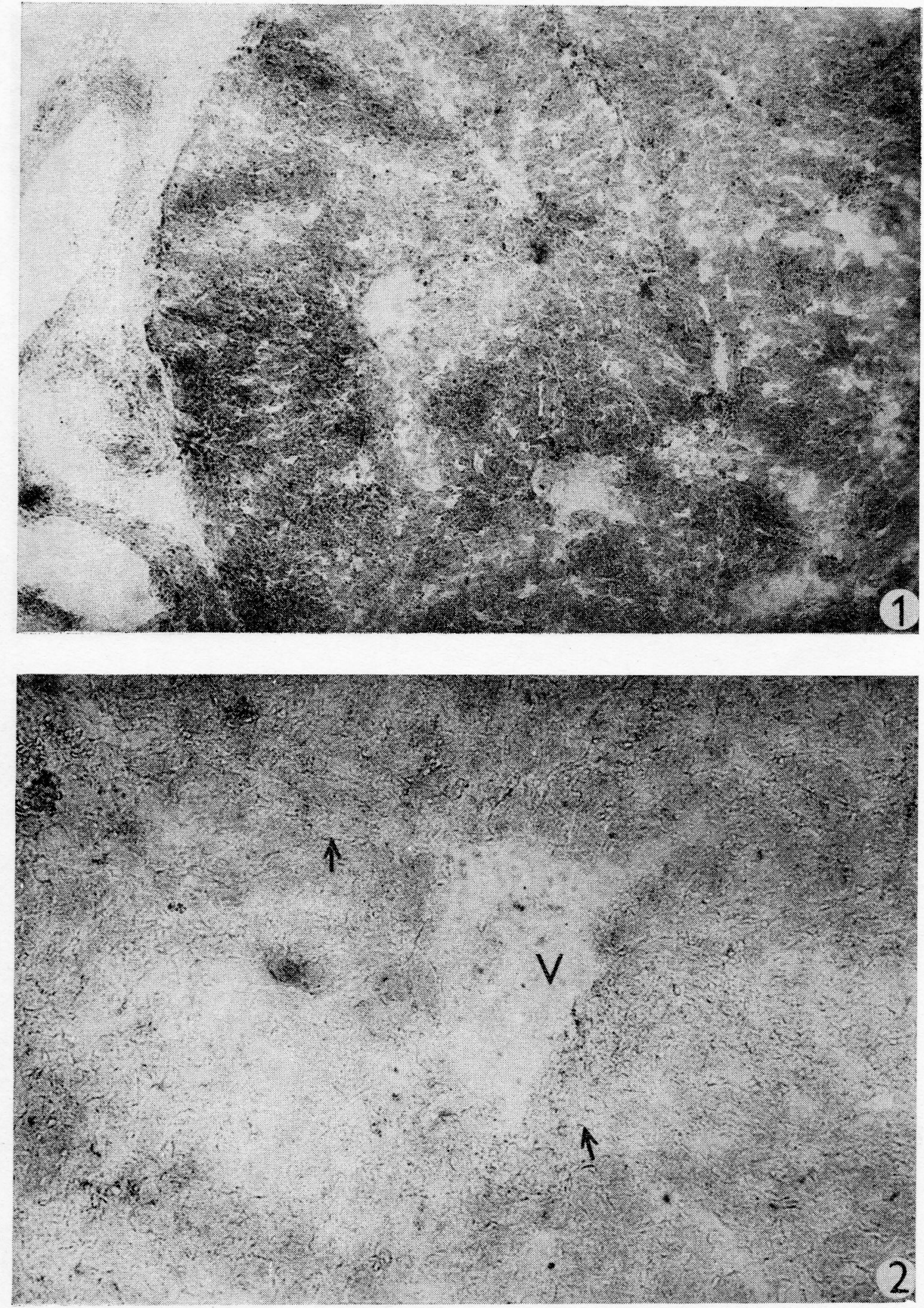

Fig. 1

A portion of liver parenchyma with lobuli. The reaction product disseminated. Control calf, alkaline phosphatase, $\times 16$.

Fig. 2

A portion of liver lobulus and v. centralis $(\mathrm{V})$. The reaction product is located on hepatocyte membranes $(\rightarrow)$. Experimental calf, alkaline phosphatase, $\times 100$. 

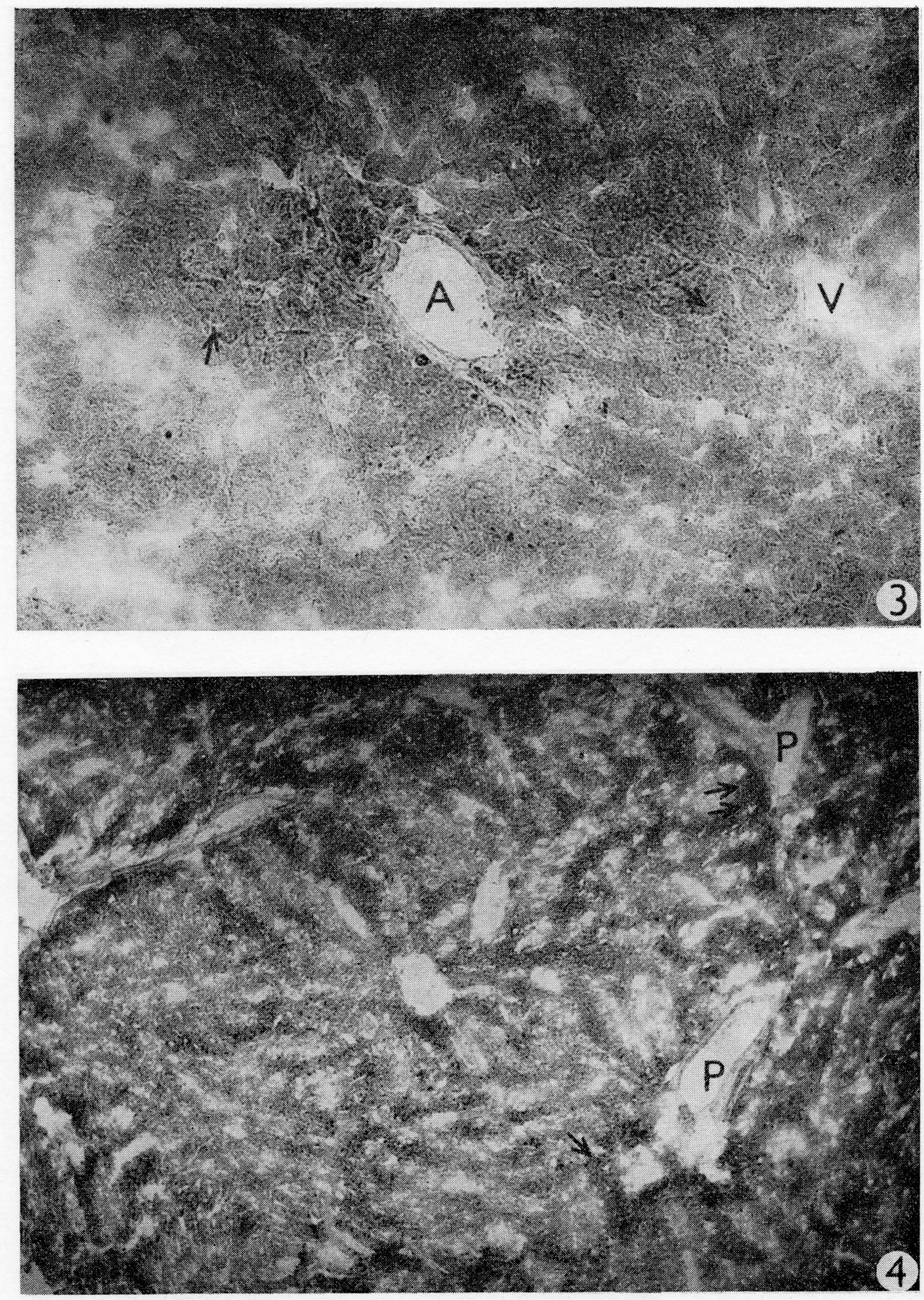

Fig. 3

Liver parenchyma with a blood vessel (A) and a portion of lobulus with v. centralis (V). In hepatocytes, few granules of the reaction product $(\rightarrow)$. Control calf, acid phosphatase, $\times 100$. Fig. 4

A portion of liver parenchyma with lobuli and portobiliary spaces $(\mathrm{P})$. The reaction product is located in peribiliary space $(\rightarrow)$. Experimental group, acid phosphatase, $\times 16$. 

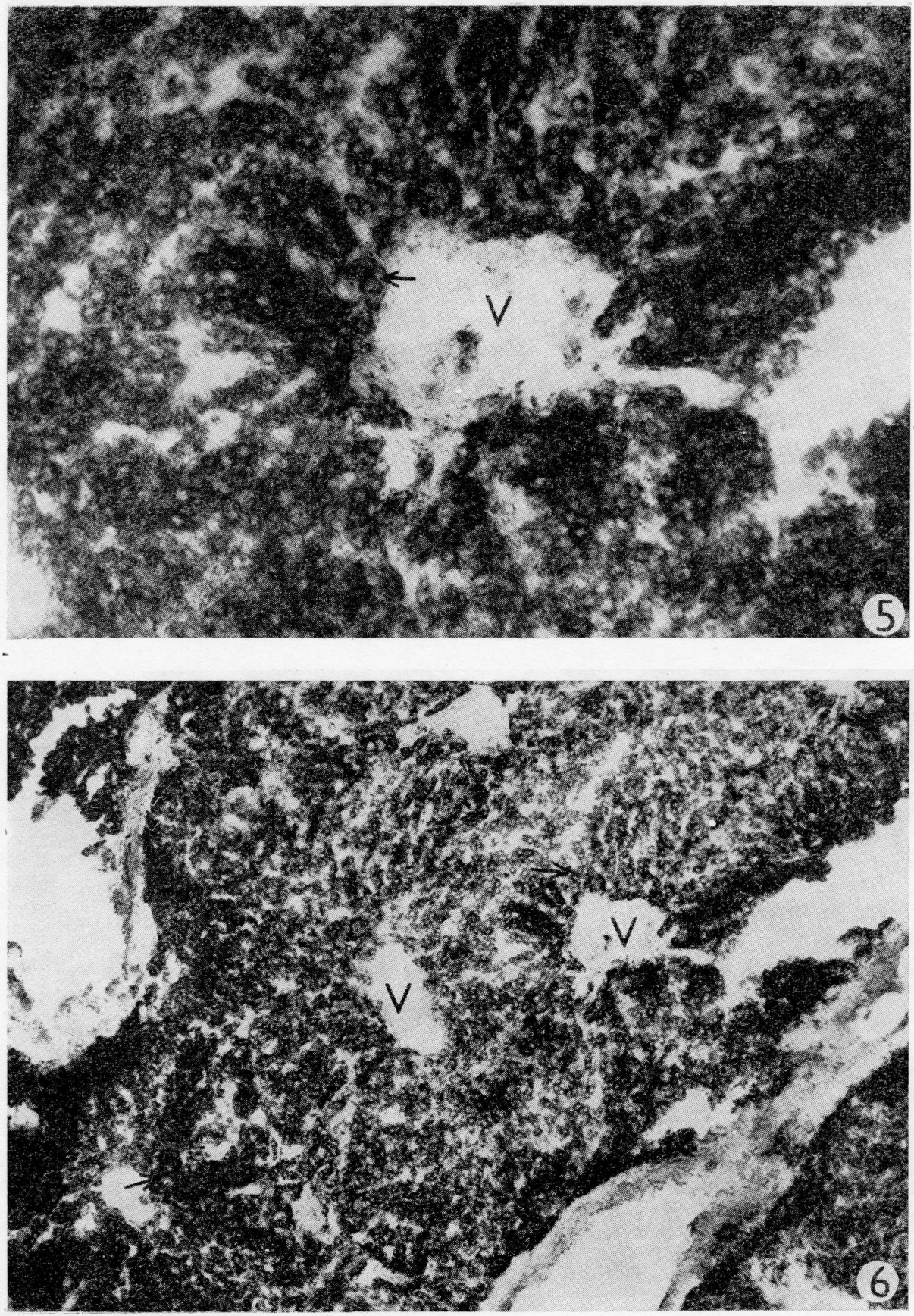

Fig. 5

A portion of liver lobulus with $\mathrm{v}$. centralis $(\mathrm{V})$. In hepatocytes large amounts of the reaction product are present $(\rightarrow)$. Control calf, lactic dehydrogenase, $\times 100$.

Fig. 6

Portions of liver lobuli with central veins $(V)$. The reaction product in hepatocytes $(\rightarrow)$. Experimental calf, lactic dehydrogenase, $\times 40$. 

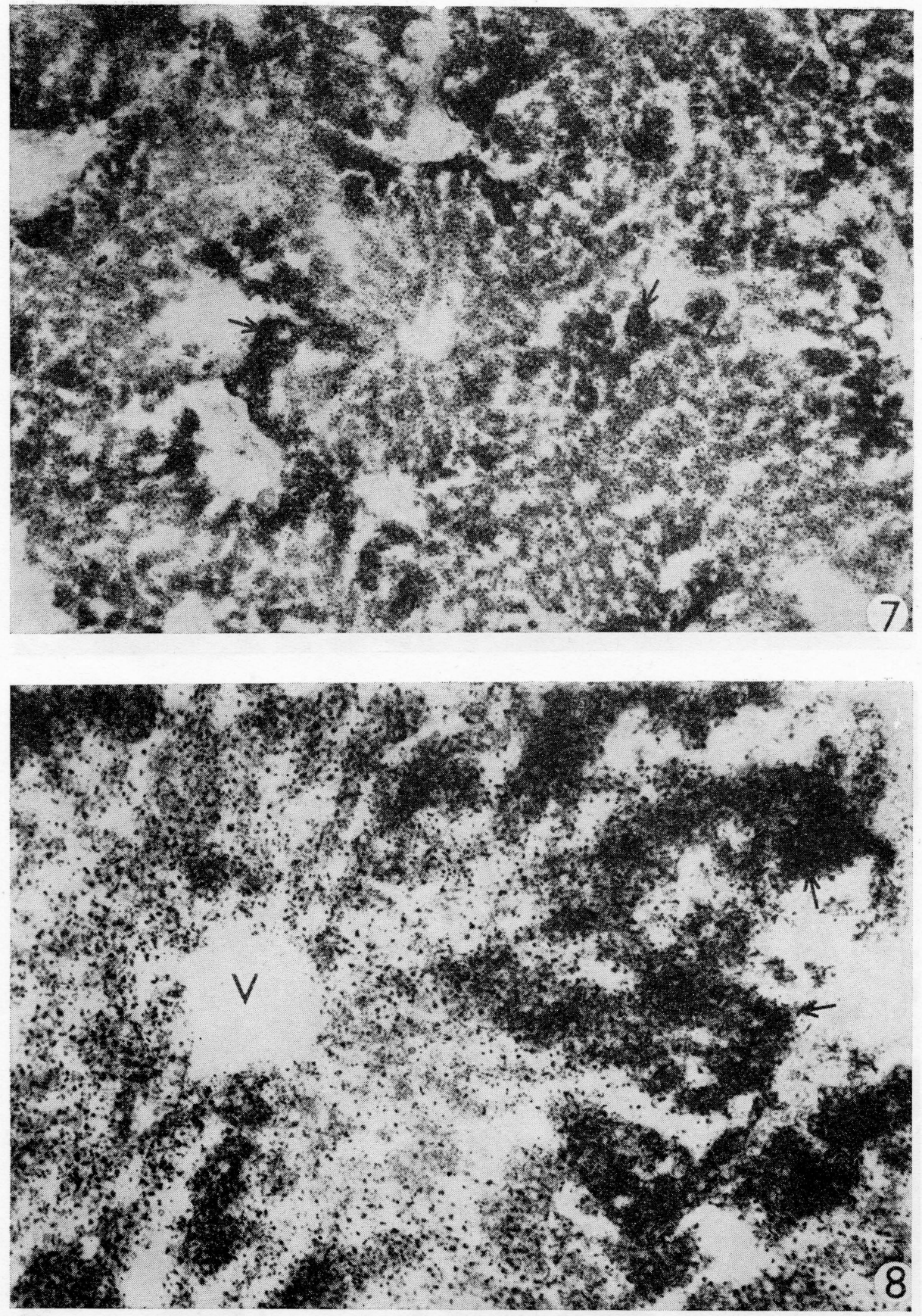

Fig. 7

A portion of liver parenchyma with lobuli. Maximum of the reaction product at the lobular periphery $(\rightarrow)$. Control calf, succinic dehydrogenase, $\times 40$.

Fig. 8

Liver lobulus with v. centralis $(\mathrm{V})$. In peripheral parts of trabeculae the reaction product is abundant $(\rightarrow)$. Experimental calf, succinic dehydrogenase, $\times 100$. 

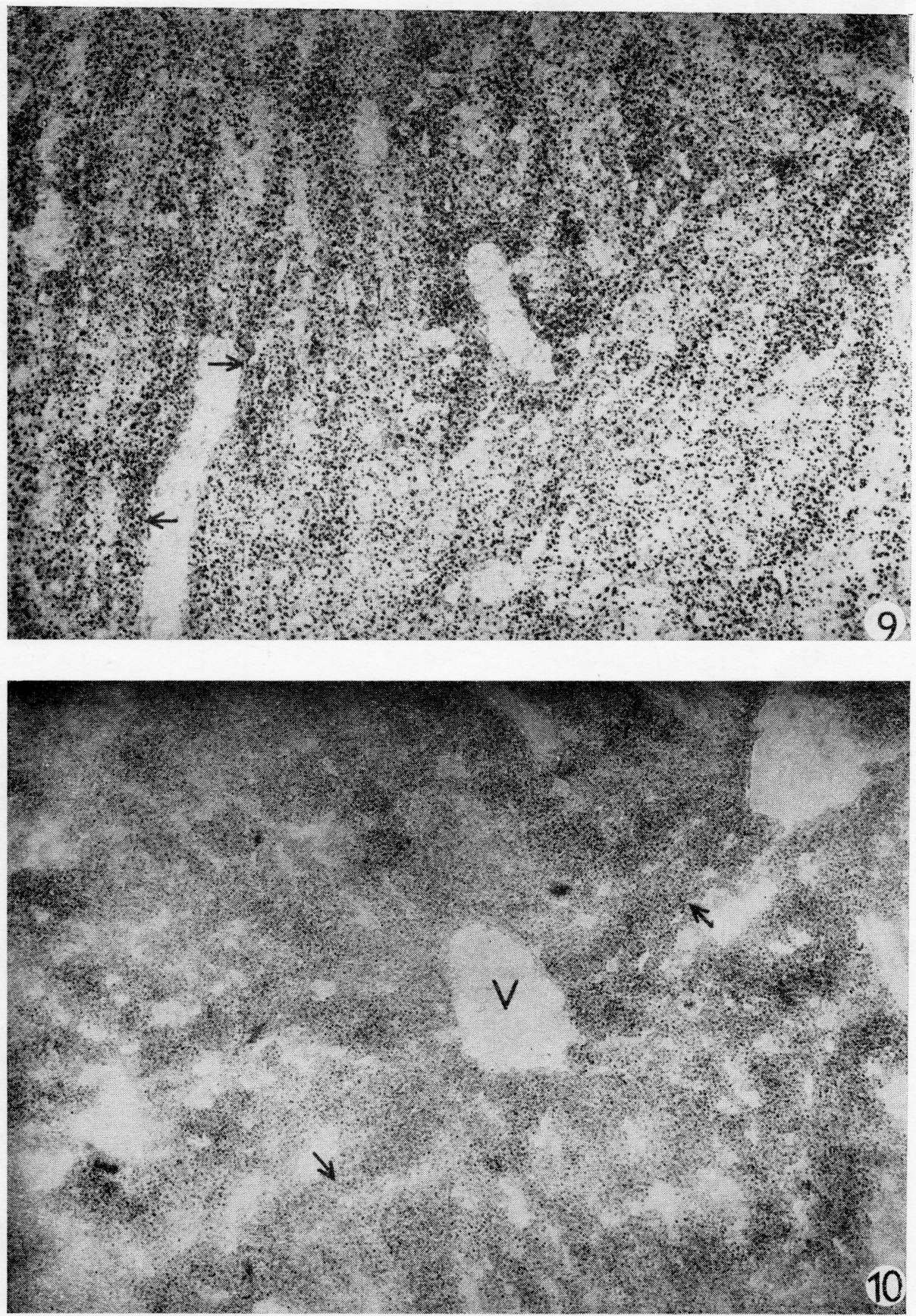

Fig. 9

Liver trabeculae with the reaction product $(\rightarrow)$. Control calf, glycerophosphate dehydrogenase, 100.

Fig. 10

A portion of liver lobulus with v. centralis $(\mathrm{V})$. The reaction product in trabeculae $(\rightarrow)$. Experimental calf, glycerophosphate dehydrogenase. $\times 40$. 

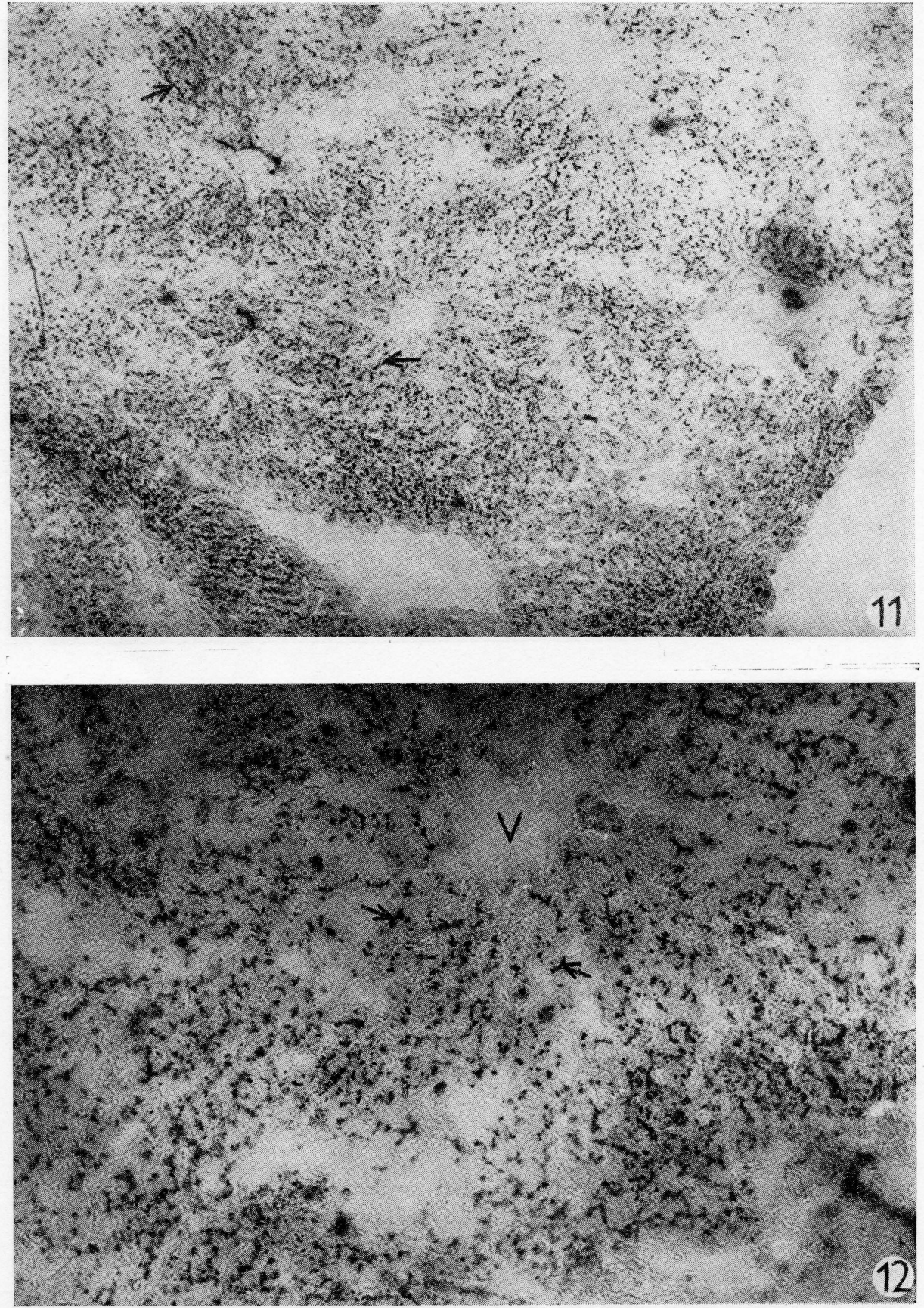

Fig. 11

A portion of liver parenchyma with lobuli. The reaction product in hepatocytes $(\rightarrow)$. Control calf, non-specific esterase. $\times 16$.

Fig. 12

A portion of liver lobulus with $\mathrm{v}$. centralis (V), the reaction product is in liver trabeculae $(\rightarrow)$. Experimental calf, non-specific esterase, $\times 100$, 

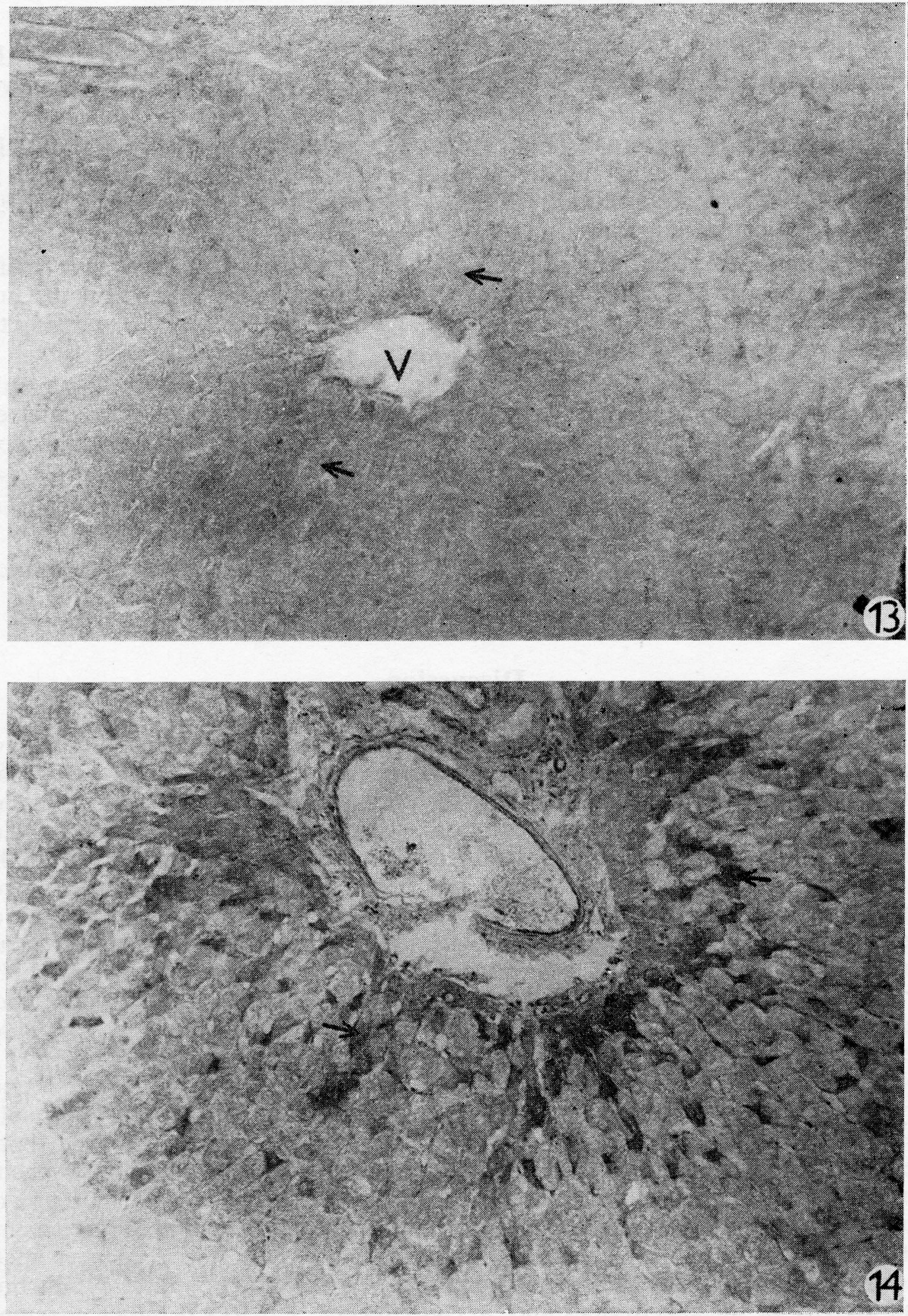

Fig. 13

A portion of liver lobulus with $v$. centralis $(\mathrm{V})$, the reaction product is present $(\rightarrow)$. Control calf PAS. $\times 100$.

Fig. 14

Portions of liver lobuli with portobiliary spaces. In its vicinity the reaction product $(\rightarrow)$. Experimental calf, PAS, $\times 100$. 
2) Acid phosphatase (Fig. 3 and 4) was located in lysosomes in vicinity of the portobiliary spaces. Its activity was found to be higher in experimental calves (grade 4).

3) Lactic dehydrogenase (Fig. 5 and 6) was disseminated throughout the liver tissue with somewhat higher activity near the portobiliary spaces and in periphery of the central vein. Its activity, however, was only 1 as against that found in the control animal.

4) Succinic dehydrogenase (Fig. 7 and 8 ) was found to have no specific location in the liver tissue. More frequent occurrence of the reaction product was found at the biliary poles of the liver lobules. Its activity in experimental animals was graded 5 .

5) Glycerophosphate dehydrogenase (Fig. 9 and 10) was predominantly found in the course of bile ducts. No differences in its activity were detected between the experimental and control animals; grade 3 was found in both groups.

6) Non-specific esterase (Fig. 11 and 12). Its topography could not be specified in our material. Its activity, directly proportional to the colour intensity of the reaction product, was much higher in experimental calves (grade 6).

7) Polysaccharides (Fig. 13 and 14). No differences were detected in location or activity of these substances (grade 3). They were found within the cells.

\section{Discussion}

Histochemical evidence and topography of enzymes in liver parenchyma have been extensively dealt with by many authors (see Lojda 1966; Wolf 1966). Our findings are in good agreement with previous data on the enzymes under study. To our knowledge, however, no data are available on the effect of Ca-deficient diet on activities of the individual liver enzymes. Comparison of the results obtained in calves fed a Ca-deficient diet with those obtained in the control animal revealed that the $\mathrm{Ca}$ deficiency adversely affects the catalytic activity of liver enzymes. After elimination of histopathological changes in the liver structure, the explanation of this fact seems to be in the role of calcium in metabolic processes. Abundant data in literature seem. to suggest that the calcium deficiency causing disbalance between the $\mathrm{Ca}$ and $\mathrm{P}$ levels is accompanied by a parallel decrease in the content of other elements, above all $\mathrm{Cu}$ and $\mathrm{Mn}$. The EDTA sodium salt binds primarily the intensively ionized calcium in the blood plasma. Hypocalcemia can result (Vant 1977; Saeki and Hayashi 1977) with a subsequent activation of the parathyroid and enhanced Ca mobilization from bone depots. For other elements only a small portion of the EDTA binding capacity remains. The EDTA sodium salt, in advance saturated with $\mathrm{Ca}$, binds predominantly metals in exchange for this calcium. Binding and excretion of elements results in changes in their levels in body fluids and tissues. These changes affect the metabolic processes dependent upon the bound elements, e. g. production and activity of metalloenzymes and, in consequence, activities of other enzymes. Also the antagonism between the $\mathrm{Ca}$ and $\mathrm{Mg}$ ions is involved ( $\mathrm{Kauf} \mathrm{1980)}$.

Increased activity of liver phosphatases in calves fed the Ca-deficient diet result from the changed $\mathrm{Ca}: \mathrm{P}$ ratio. These essential elements must be continuously supplied in the diet. Feeding a Ca-deficient diet results in enhanced P resorption increasing availability of phosphate for phosphorylating processes. Thus also 
the activity of enzymes involved in these reactions, i. e. alkaline and acid phosphatases, is increased.

The catalytic activity of lactic dehydrogenase decreased considerably in our experimental calves. In Ca-deficient animals the originally intracellular Mg passes into the extracellular spaces and lack in cytosol makes itself felt by slower glycolysis (among 9 glycolytic enzymes 4 are $\mathrm{Mg}^{24}$ dependent). Slow and restricted production of pyruvic acid affects the catalytic activity of LD (Harper 1977; Ganong 1978; Santavý 1975; Church 1971; Karlson 1963; Schreiber 1976).

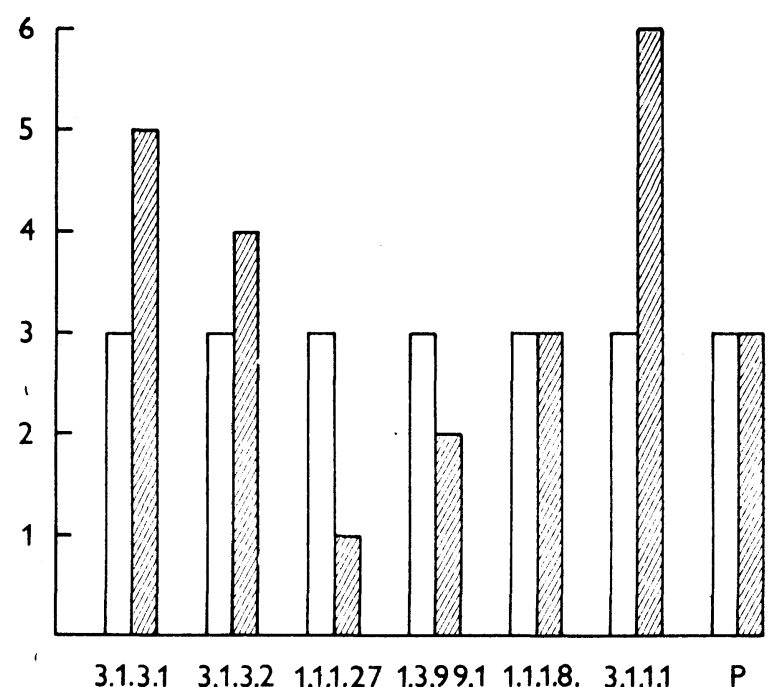

Fig. 15

Semiquantitative comparison of enzyme activities and polysaccharides in the livers of calves fed standard and $\mathrm{Ca}$-deficient diets empty columns - control calf hatched columns - experimental calves. Explanations: EC 3.1.3.1 (alkaline phosphatase), EC 3.1.3.2 (acid phosphatase), EC 1.1.1.27 (lactic dehydrogenase), EC 1.3.99.1 (succinic dehydrogenase), EC 1.1.1.8 (glycerophosphate dehydrogenase), EC 3.1.1.1 (non-specific esterase), P (polysaccharides)

Similarly, insufficient production of pyruvic acid results in lack of substrate for the citric acid cycle in which the enzyme is involved (Šantavý 1975).

Somewhat surprising was the finding of almost equal amounts of polysaccharides in the liver parenchyma of both experimental and control calves in connection with impairment of energy metabolism signalized by a depression in activity of the above-mentioned dehydrogenases in the experimental animals. However, the histochemical evidence of polysaccharides provides but pilot data and does not enable to show the fine differences in the acitivity of these substances. For their precise determination biochemical methods should be used.

Elucidation of elevated activity of non-specific esterase in liver tissue of the experimental calves is rather difficult because of lack of information on its physiological role. The individual enzymes of this group are not entirely substrate specific and they show considerable organ and species differences in kinetics and sensitivity to various inhibitors. 
The extent of changes in enzyme endowment of the liver is thus not limited to Ca-deficiency in the diet but seems to be a starting point of several secondary metabolic dysfunctions complicating the interpretation of experimental results. In conclusion in can be stated that all enzymes under study were detected in the liver tissue of calves and their location was not dependent on Ca content in the diet. It seems, however, that the catalytic activity of these enzymes is largely affected by Ca-deficiency in that activity of phosphatases is higher and that of dehydrogenases lower in animals fed the Ca-deficient diet. On the other hand, no changes were observed in the amount of polysaccharides in the liver tissue of the calves.

\section{Histotopografické určení některých enzymů $v$ játrech skotu za standardních a experimentálních podmínek}

$\mathrm{V}$ práci je popsána problematika histochemického průkazu enzymů $\mathrm{v}$ játrech telat s ohledem na možnost ovlivnění jejich topografie a intenzity katalytické aktivity deficitem kalcia $\mathrm{v}$ krmné dávce.

Byly odebrány vzorky jater telat ve stárí dvou měsíců, a to od dvou telat krmených krmnou dávkou s deficitem kalcia a od jednoho telete, odchovaného na standardní krmné dávce. Ve vzorcích byly specifickými reakcemi dokazovány následující enzymy: alkalická fosfatáza, kyselá fosfatáza, dehydrogenáza kyseliny mléčné, jantarové a glycerofosforečné a nespecifická esteráza. Dále byl metodou PAS stanoven obsah polysacharidů $\mathrm{v}$ játrech sledovaných jedinců.

Kromě histotopografického určení výše uvedených enzymů byla na základě semikvantitativního srovnání stanovena intenzita jejich katalytických aktivit.

Vyhodnocením takto získaných výsledků jsme zjistili diference $\mathrm{v}$ enzymatickém vybavení jater mezi kontrolní a experimentální skupinou, zejména se zřetelem na úroveň katalytických aktivit obou fosfatáz, dehydrogenázy kyseliny mléčné a nespecifické esterázy, jejichž aktivita byla deficitem $\mathrm{v}$ krmné dávce ovlivněna. $\mathrm{V}$ topografii sledovaných enzymů jsme nezaznamenali mezi oběma skupinami výraznějších disproporcí.

\section{Гистотопографическое определение некоторых энзимов в печени крупного рогатого скота в стандартных и экспериментальных условиях}

В работе приводится описание проблематики гистохимического определения әнзимов в печени телят с учетом возможности оказания влияния на их топографию и интенсивность каталитической активности дефицитом кальция в кормовом рационе.

Были отобраны образцы печени телят в возрасте двух месяцев, а именно у двух телят, кормленных рационом с дефицитом кальция, и у одного - содержаемого на стандартном кормовом рационе. С помощью специфических реакций на образцах устанавливались следующие энзимы: пелочная фосфатаза, кислая фосфатаза, дегидрогеназа молочной кислоты, янтарной кислоты, глицеринфосфорной кислоты и неспецифическая әстераза. Методом PAS определяли далее содержание полисахаридов в печени исследуемых животных.

Помимо гистотопографического определения вышеприведенных энзимов на основе полуколичественного сравнения определялась интенсивность их каталитических активностей. 
Оценкой полученных таким образом результатов была установлена дифференция энзиматического содержания печени между контрольной и экспериментальной группами, особенно с учетом уровня каталитических активностей обеих фосфатаз, дегидрогеназы молочной кислоты и неспецифической эстеразы, активность которых подвергалась влиянию дефицита кальщия в кормовом рационе. В топографии исследуемых энзимов не бюло установлено между обеими группами более выразительных диспропорций.

\section{References}

BEHNE, D. et al.: Bestimmung der enteralen Resorption hoher Calciumdosen mittels stabiler Isotope. Klin. Wschr. 56, 1978, 69.

BOD̃A, K., LEBEDA, M. a kol.: Patologická fyziologie hospodářských zviřat, SZN, Praha, $1972,301-313$.

GANONG, W. F.: Přehled lékařské fyziologie, Avicenum, Praha, 1978, 417-421.

HARPER, H. A.: Přehled fyziologické chemie, Avicenum, Praha, 1977, 170, 177, 195-197, $258-260,284-285,435,437,499-511$.

HEGGLIN, H. A.: Diferenciální diagnostika vnitřních chorob, Avicenum, Praha, 1972, 17, $369,867-868$.

HOLUB, A. a kol.: Fyziologie hospodářských zviřat, SZN, Praha, 1969, 136-137, 474-479.

CHURCH, D. C.: Digestive Physiology and Nutrition of Ruminants, O. S. U. Book Stores Inc. USA, 1971, Volume 2-nutritione, 417--472.

KARLSON, P.: Základy biochemie, Academia, Praha, 1963, 387-388.

KAUF, E.: Störungen des Kalziumstoffwechsels. Z. ärztl. Fortbild. 74, 1980, 13/14, 624-631.

KLIKA, E., VACEK, Z.: Histologie, Avicenum, Praha, 1974, 255-263.

LOJDA, Z.: Histo- a cytochemie enzymů, skripta, Brno, 1966, 9-18, 23-27.

NORDIN, D. et al.: Effect of Various Therapies on Bone Loss in Women. In: Calcium Metabolism, Bone and Metabolic Bone Diseases. Hrsg, von F. Kuhlencordt und H. P. Kruse, Berlin-Heidelberg-New York, 1975, 223.

POJER, J. a kol.: Enzymologie srdečního infarktu, SZdN, Praha, 1963, 1967.

POJER, J. a kol.: Enzymologie jaterních nemocí, SZdN, Praha, 1968, 29-36, 54-59.

SAEKI, T., HAYASHI, M.: Acute parathyroid response in EDTA-induced hypocalcemia and its aplication by a functional test of the parathyroid gland in cattle. Nat. Inst. Animal Health Quart. 17, 1977, 2: 67-72.

SCHREIBER, V.: Patofyziologie žláz s vnitřní sekrecí, Avicenum, Praha, 1976, 191.

ŠANTAVÝ, F.: Biochemie, Avicenum, Praha, 1975, 249-260, 116-160, 445-448, 471-488.

VACEK, Z.: Histologická technika, Avicenum, Praha, 1972, 223-224, 270-272.

VANT, T.: Hypocalcemia in bull after EDTA infusion. Variations among individuals. Nord. Veter.-Med. 29, 1977, 4/5: 237-243.

WOLF, J.: Histologie, SZdN, Praha, 1966, 534-549. 